\title{
ВПЛИВ НЕСТАБІЛЬНОСТІ СПОЖИВАННЯ НА ЕНЕРГЕТИЧНИЙ БАЛАНС ГІБРИДНОЇ ЕНЕРГОСИСТЕМИ
}

\author{
М.П. Кузнєцов ${ }^{1}$, докт. техн. наук, О.А. Мельник ${ }^{2}$, аспірант \\ ${ }^{1}$ Інститут відновлюваної енергетики НАН України, \\ 02094, вул. Гната Хоткевича, 20А, м. Київ, Україна. \\ ${ }^{2}$ Національний технічний університет України «Київський політехнічний інститут ім. Ігоря Сікорського», \\ 03056, пр-т. Перемоги 37, м. Київ, Україна.
}

\begin{abstract}
Метою даної роботи є розроблення моделі балансування проиесів генерачії та споживання електроенергії для випадків обмеженої або недостатньої інформачії про навантаження на енергетичну систему. При відсутності достатніх історичних даних про ці процеси для моделювання використовуються узагальнені статистичні показники. Цим обумовлено завищені вимоги до потреб у резервних потужностях та системах акумулювання енергії. Предметом дослідження є гібридні електроенергетичні системи, які використовують традииійні та відновлювані джерела енергї $i$ мають властивості локальної мережі. Такі системи чутливі до змінних режимів споживання енергії, які ускладнюють оцінку поточного навантаження. Наявність вітрових та сонячних електростанцій ускладнює забезпечення балансу потужності, що збільшує потребу в проміжному акумулюванні енергії. Методом дослідження локальної системи є математичне моделювання випадкових прочесів споживання та генерації енергії. Джерелом інформації про споживання є статистичні дані про робота окремих споживачів, які мають обмежену потребу в електричній енергії $і$ зацікавлені в автономних джерелах. Для таких споживачів перспективним є застосування розосередженої генерачії, в тому числі з використанням місиевих джерел сонячної та вітрової енергї. Для узагальнення даних про різних спожсивачів їх поєднано в групи відповідно до державної класифікачії видів економічної діяльності. Тоді балансування потужності можна розглядати як суперпозицію випадкових проиесів генерації та споживання. Запропонована модель навантаження дозволяє імітувати реальні процеси таким чином, щоб результати співпадали з наявними статистичними даними. Результати дослідження дозволяють порівнювати різні варіанти енергосистеми за збалансованістю та потребами в акумулюванні енергії. Бібл. 17, табл. 1, рис. 4.
\end{abstract}

Ключові слова: гібридна енергосистема, відновлювані джерела енергї̈, енергобаланс, випадковий прочес, акумулювання електроенергії.

\section{THE INFLUENCE OF INSTABILITY CONSUMPTION ON THE HYBRID ENERGY SYSTEM BALANCE}

\author{
M. Kuznietsov ${ }^{\mathbf{1}}$, doctor of technical science, $\mathbf{O}$. Melnyk ${ }^{\mathbf{2}}$, graduate student \\ ${ }^{1}$ Institute of Renewable Energy of the National Academy of Sciences of Ukraine, \\ 02094, 20A Hnata Khotkevycha St., Kyiv, Ukraine. \\ ${ }^{2}$ National Technical University of Ukraine «Igor Sikorsky Kyiv Polytechnic Institute», \\ 03056, 37 Peremohy Av., Kyiv, Ukraine.
}

The purpose of the paper is to develop a model of balancing the processes of generation and consumption of electricity for cases of limited or insufficient information about the load on the energy system. In the absence of sufficient historical data on these processes, generalized statistics are used for modeling. This is due to the excessive requirements for the needs for backup power and energy storage systems. The subjects of the study are hybrid power systems that use traditional and renewable energy sources and have local network properties. Such systems are sensitive to variable power consumption modes that complicate current load estimation. The presence of wind and solar power plants makes it difficult to ensure a balance of power, increasing the needs for intermediate energy storage. The method of the local system study is mathematical modeling of random processes of energy consumption and generation. The source of consumption information is statistics on the work of individual consumers who have a limited need for electricity and are interested in autonomous sources. The use of dispersed generation, including the use of local solar and wind energy sources, is promising for such consumers. Data on different consumers are grouped according to the state classification of economic activities. Then the power balancing process can be regarded as a superposition of random generation and consumption processes. The proposed load representation model makes it possible to simulate real processes in such a way that the results are consistent with the available statistics. The results of the study make it possible to compare different options of the power grid for balancing and energy storage needs. Ref. 17, tabl. 1, fig. 4.

Keywords: hybrid power system, renewable energy, energy balance, random process, accumulation of electricity. 


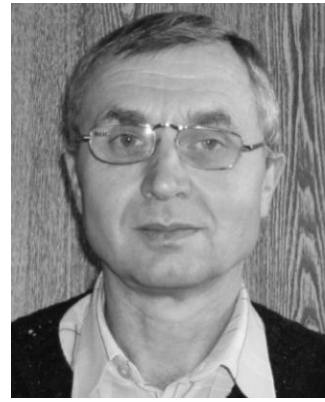

М.П. Кузнєиов M. Kuznietsov

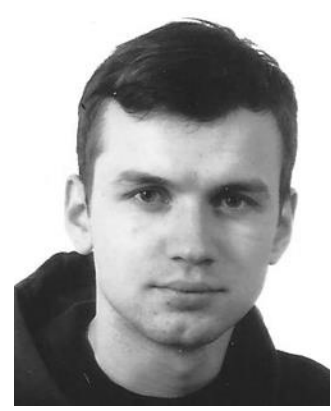

O.A. Мельник O. Melnyk
Відомості про автора: заступник директора Інституту відновлюваної енергетики НАН України, старший науковий співробітник, доктор технічних наук.

Освіта: Київський державний університет ім. Т. Шевченка, механіко-математичний факультет.

Наукова сфера: математика, відновлювана енергетика.

Публікації: понад 80.

ORCID: 0000-0002-0497-7439

Контакти:тел./факс: +38 (044) 206-28-09

e-mail: renewable@ukr.net

Відомості про автора: аспірант, інженердослідник.

Освіта: Національний технічний університет України «Київський політехнічний інститут ім.І.Сікорського», факультет

електроенерготехніки та автоматики

Наукова сфера: електроенерготехніка, відновлювана енергетика.

Публікації: 10.

ORCID: 0000-0003-2894-3476

Контакти: тел./факс: +38(044) 236-21-49

e-mail: aspirantura@kpi.ua
Author information: Deputy Director of the Institute of Renewable Energy at the NASU, Doctor of technical sciences.

Education: Taras Shevchenko Kyiv State

University, Faculty of Mechanics and

Mathematics.

Research area: mathematics, renewable energy

Publications: over 80.

ORCID: 0000-0002-0497-7439

Conatacts: tel./fax: +38 (044) 206-28-09

e-mail: renewable@ukr.net

Author information: graduate student, research engineer.

Education: National Technical University of Ukraine "Igor Sikorsky Kyiv Polytechnic Institute", Faculty of Electric Power Engineering and Automatics.

Research area: electric power engineering, renewable energy.

Publications: 10 .

ORCID: 0000-0003-2894-3476

Contacts: тел./факс: +38(044) 236-21-49

e-mail: aspirantura@kpi.ua

Перелік використаних позначень та скорочень:

ВДЕ - відновлювані джерела енергії;

ВEC - вітрова електростанція;

ЛЕС - локальна енергосистема;

CEC - сонячна електростанція;

HRES - гібридна система на основі ВДЕ;

$P$ - потужність (в.о.);

\author{
$\sigma$ - середньоквадратичне відхилення (СКВ); \\ $E_{\Delta}$ - накопичена енергія небалансу (в.о.); \\ $x$ - рівномірно розподілена випадкова величина; \\ $\varepsilon$ - нормально розподілена випадкова величина; \\ $\kappa \gamma-$ квантиль розподілу імовірності порядку $\gamma$; \\ $X(t)$ - випадкові пульсації потужності в момент часу $t$.
}

Вступ. Більшість проблем, що стосуються масштабного впровадження відновлюваних джерел енергії (ВДЕ), пов'язано $з$ нерівномірним режимом їх генерації. Змінний i слабо прогнозований характер видачі потужності, властивий вітровій та сонячній енергетиці, може привести до негативного впливу на режими роботи енергосистеми. Робота потужних вітроелектричних (BEC) та сонячних (CEC) електростанцій у складі національної енергосистеми має певне нормативнозаконодавче регулювання, їх вплив дещо компенсується за рахунок загальної ємності енергосистеми. Разом 3 тим, враховуючи розосереджений характер ВДЕ та наближеність до кінцевого споживача, було б доцільно розглядати самостійне використання ВДЕ в комплексі з іншими джерелами. В цьому випадку група ВЕС чи СЕС разом із споживачем можуть розглядатися як локальна енергосистема (ЛЕС). Ї̈ї можна визначити як сукупність генеруючого електрообладнання обмеженої потужності, перетворювачів та споживачів електроенергії, з'єднаних між собою 3 урахуванням топології розподільної мережі, у яких протікають єдині електромагнітні процеси [1]. В цьому випадку

можливо розглядати змінну генерацію вітросонячними електростанціями та споживання їх енергії як єдиний випадковий процес. Частка енергії, що споживається ЛЕС з загальної мережі, при цьому зменшується на величину генерації ВДЕ, натомість зростають вимоги до балансування локальної мережі.

Аналіз останніх досліджень i публікацій. Задачі організації обмежених енергосистем зі значною часткою ВДЕ знайшли досить широке відображення в науковій літературі. Навіть перелік оглядових статей на цю тему містить десятки публікацій. Особливо зросла кількість робіт в останне десятиліття, коли істотне здешевлення технологій на базі ВДЕ (особливо фотоелектричних) та проблеми традиційної енергетики викликали інтерес до спорудження автономних та гібридних енергосистем. В роботі [2] наведено огляд досліджень стосовно стійкості автономних енергосистем, що використовують ВДЕ, залежно від потужностей, наявності акумулювання енергії, систем керування. Гібридні енергосистеми типу мікромереж, що використовують вітрову, сонячну енергію та паливні елементи, розглядаються в роботі [3]. Представлено огляд різних технологій 
розподіленої генерації, інтеграції різних ВДЕ для створення гібридної системи, можливості регулювання вихідної потужності. В роботі [4] представлено огляд публікацій щодо методів оптимізації, придатних для малих та ізольованих систем. Обгрунтовано застосування моделей на основі штучного інтелекту для задач оптимізації гібридної системи на основі відновлюваної енергії (HRES). Огляд публікацій стосовно оптимальної побудови таких гібридних систем міститься також в [5]. Розглянуто декілька типових прикладів гібридних систем, забезпечення надійності та економічної ефективності HRES. Різноманітні конфігурації вітро-сонячних систем, стратегію управління, техніко-економічний аналіз та соціальний ефект розглянуто в дослідженні [6]. За результатами огляду запропоновано шляхи вдосконалення конструктивного виконання та систем управління гібридних систем на прикладі конкретних регіональних умов. Техніко-економічний аналіз виконано 3 застосуванням спеціальних розрахункових методів та засобів (HOMER, PSO). Огляд можливих конфігурацій HRES, методів математичного моделювання та стратегії управління наведено в роботі [7]. За результатами огляду різних робіт зроблено ряд висновків, зокрема: гібридні системи можуть бути життєздатною альтернативою електромереж або традиційного палива для віддалених районів у всьому світі; для розрахунку таких систем доцільними є евристичні методи, особливо при врахуванні стохастичних параметрів; кращі результати 3 точки зору надійності та вартості мають системи 3 кількома джерелами енергії сонце, вітер, централізована мережа; важливим $є$ попереднє врахування як місцевих кліматичних умов, так і особливостей попиту на енергію. Серед робіт останніх років можна відзначити [8], де досліджуються технічні проблеми гібридних систем та порівнюються режими роботи 3 мережею i автономно. Розглядаються також можливості мінімізації ризиків та втрат енергії. Окремі задачі побудови автономної системи 3 ВДЕ та накопиченням енергії розглянуто в [9]. В якості проміжного енергоносія пропонується використовувати водень як засіб зберігання енергії; пропонуються оптимальні рішення для електрифікації віддаленої громади.

Постановка завдання. Організація роботи ВДЕ у складі локальних систем має спиратись на попередні дослідження як природного вітрового та сонячного потенціалу (тобто кліматичних умов регіону), так i режиму навантаження (характеру споживання енергіi). У випадку електроенергетичної системи мова йде про очікувані графіки генерації та навантаження, відповідно до яких планується використання генеруючих потужностей певних видів. В якості інформації для дослідження реальних режимів роботи локальних споживачів та ї математичного моделювання слугують історичні дані стосовно швидкості вітру, сонячної радіації та фактичного споживання, яке є навантаженням на енергосистему. Запис фактичних значень генерації та споживання за певний період формується як часовий ряд, що полегшує статистичну обробку та математичне моделювання.

Стосовно метеорологічних факторів (вітру, сонячної радіації) існують архівні дані гідрометеослужб, а також діючих ВЕС та СЕС. Ці дані мають різні умови вимірювань (висоту установки датчика, часову дискретність, точність), тому при дослідженні балансу потужностей та енергії мають бути представлені однаковим чином, шляхом попередньої статистичної обробки та агрегування. Натомість джерела інформації щодо режимів споживання менш доступні і різноманітніші за способами представлення. Зокрема, споживання всієї енергосистеми відображується на державному веб-порталі відкритих даних [10]. Інформація про окремі групи споживачів, згрупована за кодами економічної діяльності [11], наведена в дослідженні [12]. Особливістю цього дослідження є попередня статистична обробка історичних даних, в результаті характерний графік електричного навантаження подано як усереднений ступінчатий (погодинний) графік навантаження для ряду споживачів, аналогічних (близьких) за видом економічної діяльності, режимом роботи та набором електрообладнання. Для кожної години місяця обчислено математичне очікування активних навантажень $\left(P_{c}\right)$ та середньоквадратичне відхилення $(\sigma)$. Для нормування характерного графіка навантажень його приведено до виду, коли максимум $P$ дорівнює 100 кВт (або 100\%). Деякі приклади нормалізованих графіків навантажень (активної потужності), осереднені для груп споживачів та для окремих місяців за порами року, наведено в табл. 1 та зображено на рис. 1. Використано показники тих споживачів, які можуть розглядатись як відокремлені невеликі підприємства у складі локальної енергосистеми. 
Таблиця 1. Середньомісячні значення та стандартні відхилення нормалізованої активної потужності деяких груп споживачів.

Table 1. Monthly averages and standard deviations of the normalized active power of some consumer groups.

\begin{tabular}{|c|c|c|c|c|c|c|c|}
\hline \multirow{2}{*}{ Місяць } & \multirow{2}{*}{$\begin{array}{c}\text { Показник } \\
(\%)\end{array}$} & \multicolumn{5}{|c|}{ Вид економічної діяльності* } & \multirow[t]{2}{*}{ Середне } \\
\hline & & 10.39 & 10.41 & 10.85 & 10.91 & 47.30 & \\
\hline \multirow{2}{*}{ Січень } & $P_{c}$ & 73,8 & 71,8 & 62,4 & 73,5 & 82,9 & 72,9 \\
\hline & $\sigma$ & 65,8 & 17,1 & 26,4 & 31,8 & 37,5 & 35,7 \\
\hline \multirow{2}{*}{ Квітень } & $P_{c}$ & 76,0 & 75,1 & 69,3 & 72,1 & 81,1 & 74,7 \\
\hline & $\sigma$ & 36,7 & 34,2 & 26 & 30,6 & 28,1 & 31,1 \\
\hline \multirow{2}{*}{ Липень } & $P_{c}$ & 69,3 & 65,4 & 62 & 67,8 & 88,3 & 70,6 \\
\hline & $\sigma$ & 30,6 & 25,5 & 38,5 & 22,7 & 28,9 & 29,2 \\
\hline \multirow{2}{*}{ Жовтень } & $P_{c}$ & 74,2 & 76,1 & 68,8 & 75,3 & 72,5 & 73,4 \\
\hline & $\sigma$ & 32,3 & 31,6 & 65,6 & 31,7 & 36,9 & 39,6 \\
\hline \multirow{2}{*}{ Рік } & $P_{c}$ & 73,3 & 72,1 & 65,6 & 72,2 & 81,2 & $\mathbf{7 2 , 9}$ \\
\hline & $\sigma$ & 41,3 & 27,1 & 39,1 & 29,2 & 32,8 & $\mathbf{3 3 , 9}$ \\
\hline
\end{tabular}

*Національний класифікатор України ДК 009:2010:

10.39 - Перероблення та консервування фруктів і овочів;

10.41 - Виробництво олії та тваринних жирів;

10.85 - Виробництво готової їжі та страв;

10.91 - Виробництво готових кормів для тварин, що утримуються на фермах;

47.30 - Роздрібна торгівля пальним.

Результати дослідження. Візуальне досить близькі, що дозволяє застосувати представлення початкових даних $з$ табл.1 (рис.1) узагальнені математичні моделі, які імітували б наглядно демонструє, що традиційний типовий графік споживання електроенергії осереднений для групи споживачів добовий хід локальним споживачем типу малого споживання є досить стабільним впродовж року, підприємства.

3 вираженим добовим ходом. При цьому показники окремих груп споживачів також

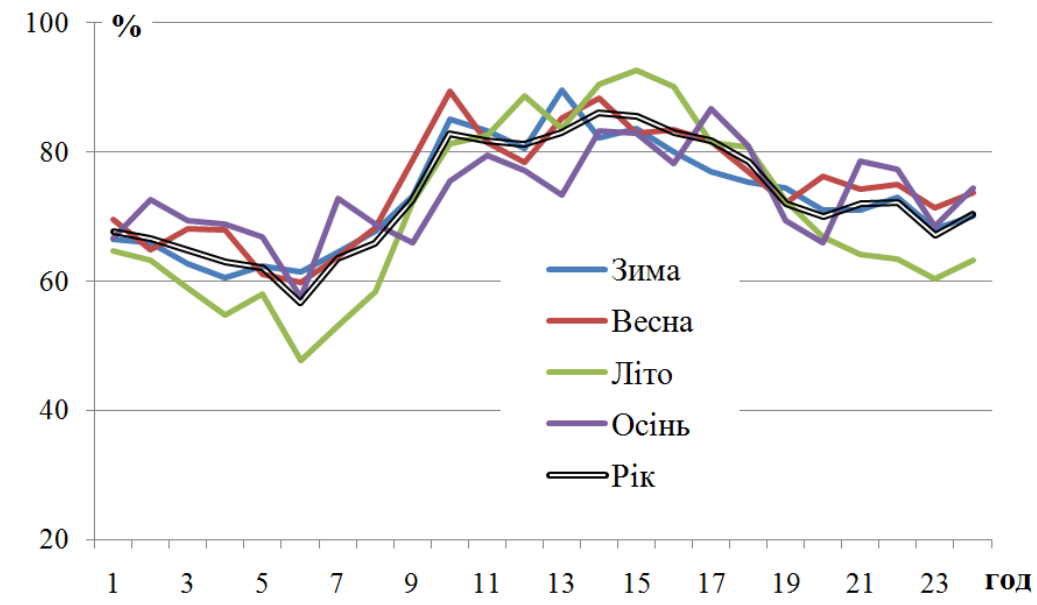

Рис. 1. Типові графіки електричних навантажень для кількох груп споживачів.

Fig. 1. Typical electrical load charts for multiple consumer groups.

Недоліком використаних даних $\epsilon$ їх нормалізація максимальним математичним очікуванням, а не номінальною потужністю. Адже максимальні значення теоретично можуть відхилятися від середнього відповідно до правила «трьох сигм» $(3 \sigma)$. Однак особливістю розглянутих локальних споживачів $є$ обмежений перелік електричного обладнання, тобто максимально досяжна (номінальна) потужність мало відрізнятиметься від осередненої за годину в часи робочого режиму 3 повним навантаженням. Для оцінки номінальної 
потужності можна використати коефіцієнти форми як відношення середньоквадратичного значення $\left(P_{c k}\right)$ до середнього, наведені в цитованому альбомі типових графіків [12]. Їх значення знаходяться в межах 1,02-1,10, але в середньому рівні 1,04 . Оскільки $P_{c \kappa} €$ незміщеним стандартним відхиленням, а середнє відповідає математичному очікуванню, то $\sigma^{2}=P_{c k}^{2}-P_{c}^{2}$, i максимальні значення можна наближено прийняти: $P_{\max }=1,25 P_{c}$.

Параметричний опис електричного навантаження 3 використанням осереднених помісячно даних дозволяє побудувати імітаційну модель 3 високим рівнем невизначеності. Така модель допускає значні відхилення від лінії тренду (осередненого добового ходу); не визначеним залишається також темп зміни потужності за одиницю часу. Традиційний метод представлення випадкових процесів такого роду - сума середнього та випадкової величини, яка моделюється різними підходами:

$$
\begin{gathered}
P(t)=P_{c}\left(t_{i}\right)+X(t)=1 / \Delta t \int_{t_{i}}^{t_{i}+\Delta t} P(\tau) d \tau+X(t), \\
t \in\left[t_{i}, t_{i}+\Delta t\right),
\end{gathered}
$$

де $P(t), P_{c}\left(t_{i}\right)$ - миттєве i середнє значення потужності на інтервалі осереднення; $X(t)$ пульсації потужності навантаження відносно середнього значення.

За визначенням математичне очікування пульсацій: $\quad M\{X(t)\}=0 . \quad$ Середні $\quad$ значення середньоквадратичних відхилень (СКВ) пульсацій на годинних часових інтервалах рівні $\sigma$ 3 табл.1. Крім того, $0 \leq P(t) \leq P_{\max }$, що накладає відповідні обмеження на розмах $X(t)$.

Характер розподілу пульсацій як випадкових величин в загальному випадку не визначений. Якщо припустити подібність 3 розподілом середніх потужностей, то він може моделюватися суперпозицією нормального та рівномірного розподілів на обмеженому інтервалі:

$$
\begin{aligned}
& X(t)=a\left(x_{1}-0,5\right)+b \sqrt{-2 \ln \left(x_{2}\right)} \sin \left(2 \pi x_{3}\right), \\
& \quad-P_{c}(t) \leq X(t) \leq P_{\max }-P_{c}(t),
\end{aligned}
$$

де $x_{k}$ - рівномірно розподілена на інтервалі $(0,1)$ випадкова величина (т.зв. «білий шум»); $a$ та $b-$ певні коефіцієнти. Перший доданок моделює рівномірний розподіл, другий - нормальний розподіл.

Вираз (2) не враховує кореляції суміжних значень випадкового процесу, оскільки відсутні відповідні початкові дані. Інша особливість моделі - наявність локальних максимумів в області мінімальних та максимальних значень, спричинених обмеженнями (2). Ця особливість характерна для споживачів, які можуть перебувати в стані як повного, так і нульового навантаження. Так, для малих підприємств можливі дні як повного навантаження, так i простою [13] (рис. 2):

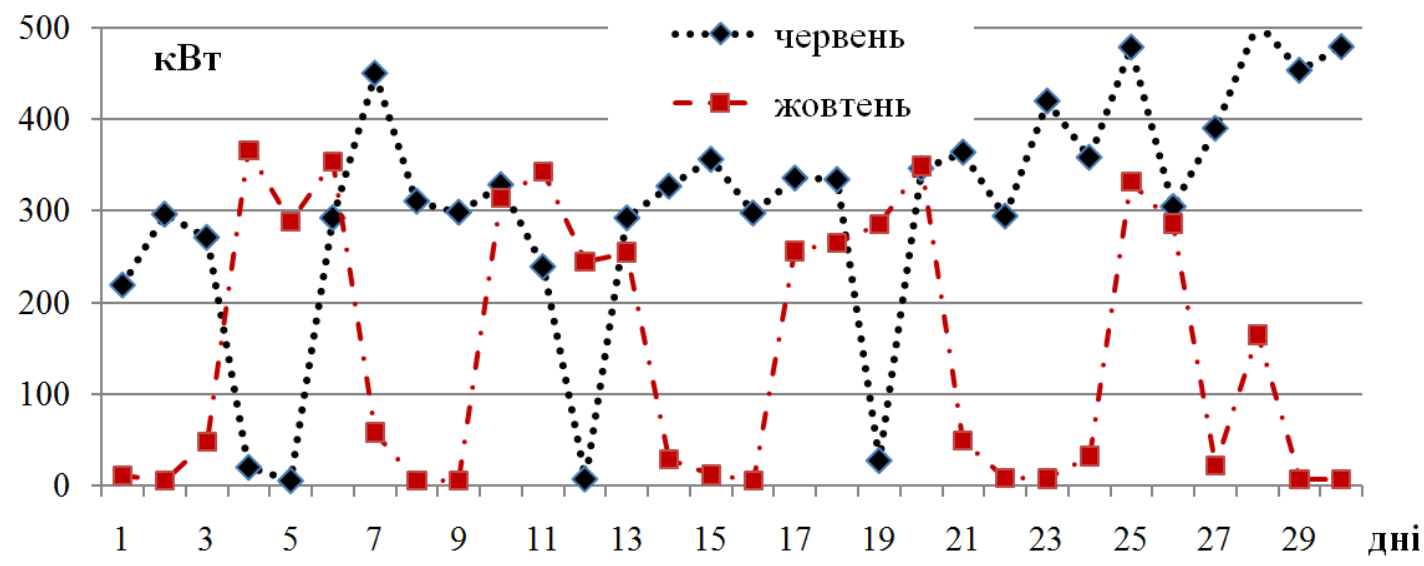

Рис. 2. Приклад змін електричної потужності впродовж місяця (мале підприємство).

Fig. 2. Example of changes in electrical power during the month (small business).

Натомість для споживачів, що містять поточні потужності знаходяться в певному значну кількість окремих незалежних коридорі (рис. 3). навантажень (наприклад, для населеного пункту) 


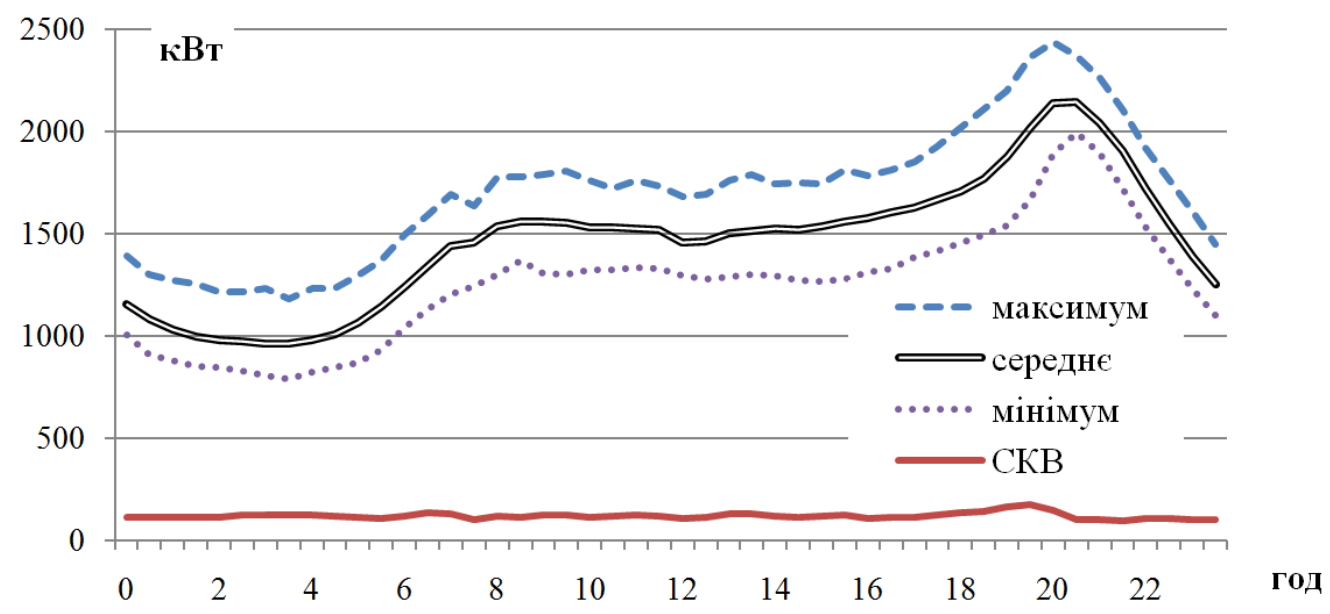

Рис. 3. Приклад добового ходу потужності для населеного пункту.

Fig. 3. Example of daily power flow for a settlement.

Відмінність між окремими днями (рис. 2) свідчить більше про неритмічність виробничого процесу, аніж про поточні пульсації усталеного режиму. Підприємства, де виробничий цикл потребує постійної роботи обладнання, мають стабільніші показники споживання протягом робочого часу, зміщуються лише сезонні максимуми. При наявності історичних даних, які містять послідовності значень у вигляді часового ряду, математична модель може бути вдосконалена введенням середньодобової складової та відповідного аналітичного виразу для пульсацій потужності [14]:

$$
P(t)=\omega(t)+\sigma_{a d} \cdot \varepsilon+U(t),
$$

де $\omega(t)$ - осереднена крива, що імітує добовий хід; $\sigma_{a d}$ - стандартне відхилення середньодобових значень; $\varepsilon$ - стандартна нормально розподілена випадкова величина; $U(t)$ - випадкова складова, що описує пульсації в момент часу $t$ i описує відповідний процес (характерним прикладом $\epsilon$ процес Орнштейна-Уленбека [15]. Модель такого процесу подібна до (2), але враховує наступність послідовних значень. Це необхідно для оцінки кумулятивних показників потужності, тобто накопичення енергії. Такого роду процеси більш характерні для населених пунктів.

Сучасна практика роботи електроенергетичної системи передбачає наявність планових графіків споживання енергії в часовій перспективі 1-2 доби. При цьому фактичні відмінності рівня навантаження від заявленого графіка вважаються небалансом потужності, тобто негативним фактором. Це стосується і гібридних енергосистем. Порівняємо оцінки кумулятивного небалансу (тобто втрат енергії чи споживання) за наявності різного інформаційного наповнення математичної моделі. Модель (1) стосується загального представлення випадкових процесів, модель
(2) оперує тільки осередненими помісячно даними для однотипних груп споживачів, при відсутності фактичних часових рядів даних. Дана модель описує рівень навантаження в кожен окремий часовий інтервал. Початковою умовою вважається наявність планового графіка навантаження, який відповідає осередненому графіку $P_{c}\left(t_{i}\right)$. Відхилення від нього $X(t)$ вважаються небалансом потужності з відповідним знаком. Небалансом енергії буде інтегральна характеристика небалансу потужності для неперервної чи дискретної схеми:

$$
E_{\Delta}(t)=\int_{0}^{T} X(\tau) d \tau \text { або } E_{\Delta}\left(t_{n}\right)=\sum_{1}^{n} X\left(t_{i}\right) \Delta t_{i}
$$

Оскільки початкові числові дані (табл. 1) сформовані шляхом оцінки погодинних значень, будемо користуватися дискретною схемою 3 постійним часовим кроком: $\Delta t_{i}=1$ год. Тоді інтегральна оцінка енергії буде чисельно рівною сумі пульсацій потужності. Отже, кумулятивна енергія може бути модельована як сума незалежних випадкових величин (за гіпотези незалежності суміжних пульсацій, що грунтується попередніх дослідженнях, див. напр. [14]). Оскільки характер розподілу окремої випадкової величини задано (2), розподіл їх суми можна описати, використовуючи згортку функцій щільності розподілу. Можливе спрощення розрахунку відповідно до центральної граничної теореми, математичне очікування суми буде дорівнювати сумі середніх, а дисперсія сумі дисперсій.

В досліджуваному випадку кількість доданків може варіювати від 24 (добова реалізація) до 720-744 (місячний обсяг). Таким чином, для моделі (2) з високою точністю можна вважати: 


$$
\begin{aligned}
& E_{\Delta}\left(t_{n}\right)=M\left\{\sum_{1}^{n} X\left(t_{k}\right)\right\}=0, \\
& D\left\{E_{\Delta}\left(t_{n}\right)\right\}=n \cdot\left(a^{2} / 12+b^{2}\right),
\end{aligned}
$$

де позначено: $M-$ символ математичного очікування, $D$ - дисперсії. Враховано властивості деяких стандартних розподілів:

$$
M\{x-0,5\}=M\{\varepsilon\}=0 ; D\{x\}=1 / 12 ; D\{\varepsilon\}=1 .
$$

Розглянемо приклади застосування пропонованої моделі для зазначених вище споживачів. Для зручності вважатимемо потужність нормованою у відносних одиницях стосовно максимального математичного очікування (на відміну від відсотків на рис. 1), маємо:

$$
\begin{gathered}
a=1,0 ; b=0,2 ; \text { тоді } \\
D\left\{E_{\Delta}\right\}_{n=24}=2,96 ; D\left\{E_{\Delta}\right\}_{n=720}=88,8 .
\end{gathered}
$$

Це відповідало б стандартним відхиленням енергобалансу за підсумком доби: $\sigma_{24}=1,7$; для місячного набору даних маємо: $\sigma_{720}=9,4$ (враховуючи $\sigma=\sqrt{D})$. Перший випадок (24 години) відповідає так званій добовій циклічності - коли на початку доби баланс вважається нульовим. Це характерно для систем 3 щоденним прогнозуванням, за умови передбачення середнього рівня споживання. У другому випадку накопичена енергія лише переходить з системи в акумулятор і назад, при цьому ефективність акумулювання (граничні обсяги, втрати, швидкодія) не враховуються. Така робота характерна для систем, розрахованих за багаторічними даними щодо середньомісячного споживання, без поточного коригування графіків навантаження, що потребує більшої компенсації імовірного небалансу.

Виконаємо імітаційне моделювання небалансу потужності відповідно до (2). Зазначимо, що отримані результати мають імовірнісну природу, та відповідають теоретичній моделі 3 урахуванням закону великих чисел. При цьому середні стандартні відхилення накопиченого небалансу впродовж доби (а не на кінець терміну) становили: $\sigma_{\partial}=1,17$ для добового циклу, та $\sigma_{\partial}=5,6$ для місячного циклу. Розподіл небалансу в межах циклу відповідає нормальному. Тоді для довірчої імовірності $\gamma$ максимальна кумулятивна потужність (тобто накопичена енергія) може оцінюватися за величиною $\kappa_{\gamma} \sigma_{\partial}$, де $\kappa_{\gamma}-$ квантиль порядку $\gamma$ [16], тобто імовірність знаходження в певних межах дорівнює:

$$
\operatorname{Prob}\left\{E_{\Delta}\left(t_{i}\right)<\kappa_{\gamma} \sigma_{\partial}\right\}=\gamma .
$$

Як правило, встановлений графік споживання передбачає деякі допустимі відхилення, тоді небалансом є потужність поза межами допустимого коридору, а надлишкова енергія $\epsilon$ кумулятивною сумою небалансу потужностей 3 урахуванням його знаку [17]. Нехай коливання поточної потужності в межах $\left(-P_{1}, P_{2}\right) \quad$ відносно планового графіка навантаження вважається допустимим, тоді небалансом буде вихід за межі цього діапазону. 3 заданою довірчою імовірністю надлишкова потужність навантаження становитиме $\left(\kappa_{\gamma} \sigma-P_{2}\right)$, рис. 4. Аналогічно визначається надлишкова генерація.

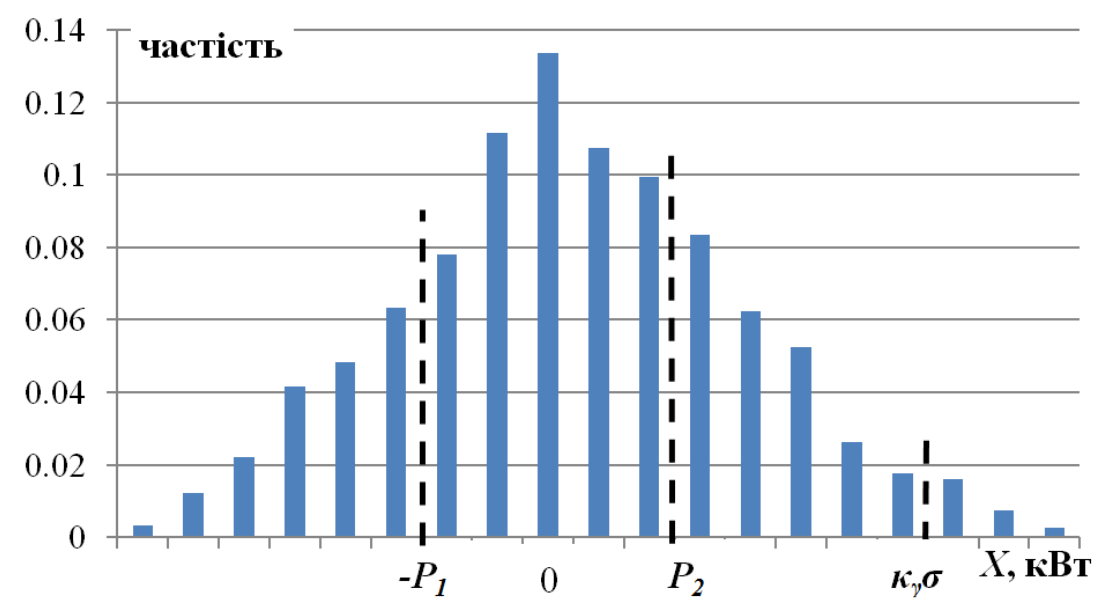

Рис. 4. Приклад гістограми розподілу небалансу потужності.

Fig. 4. Example of a power unbalance distribution histogram.

Наприклад, для довірчої імовірності $\gamma=0,9$ Середнє значення СКВ приймаємо $\sigma_{\partial}=0,34$ при нормальному розподілі маємо $|\kappa|_{0,9}=\kappa_{0,95}=1,65$. (див. табл. 1). Отже, гарантоване 3 імовірністю не 
нижче 90\% максимальне значення пульсацій потужності має становити 0,56. Таким же чином за результатами імітаційного моделювання визначається обсяг накопиченої надлишкової енергіï:

$$
\begin{gathered}
\kappa_{\gamma} \sqrt{D\left\{E_{\Delta}(t)\right\}}=1,65 \cdot 1,17=1,93 \text { при } n=24 ; \\
\text { або } \\
1,65 \cdot 5,6=9,24 \text { при } n=720 .
\end{gathered}
$$

Отже, для споживача номінальною потужністю $P_{0}$ (кВт) гарантований 3 надійністю $90 \%$ баланс забезпечується при виборі акумулятора потужністю $\sim 0,6 P_{0}$ (кВт), а ємність має становити $2 P_{0}$ (кВТ-год) при добовій циклічності, або 10P0 при місячній (потрібну ємність акумуляторів визначає досяжне накопичення енергіï). Ця оцінка $є$ досить наближеною, оскільки вона справедлива для значної кількості реалізацій, і в конкретних прикладах (до 30 днів) може відрізнятися випадковим чином. Однак така оцінка дозволяє порівнювати різні варіанти обмежень та конфігурації енергосистеми. Крім того, даний метод передбачає точний збіг середніх значень планового (за графіком) та фактичного споживання енергії, коли небаланс спричиняють лише випадкові пульсації 3 нульовим математичним очікуванням. Тоді обсяги надлишкової та недопоставленої енергії будуть чисельно рівними. Насправді таке співпадіння має певну похибку, яка може спричинити значно більшу потребу в акумулюванні енергії через кумулятивний ефект. На відміну від резервування потужності, для якого важливим є розмах відхилень навантаження від графіка, для роботи акумуляторів енергії важлива також послідовність відхилень, що не враховується в даній моделі (2), де суміжні значення повністю незалежні. В моделі (3) допускається певна послідовність пульсацій одного знаку, а небаланс енергії як інтегральна характеристика потужності залежить від тривалості відхилень одного знаку.

Приклад (9) стосується варіативності навантаження, коли генерація відбувається строго за плановим графіком. При застосуванні ВДЕ генерована складова також матиме випадкові пульсації, поряд 3 осередненим за даними спостережень добовим ходом. Тоді випадкові параметри небалансу будуть визначатися сумою незалежних процесів генерації та споживання. Величина параметрів має визначатися 3 урахуванням кліматичних та сезонних особливостей, а також енергетичних характеристик обладнання ВЕС та СЕС. Перехід на ВДЕ вимагатиме значно більшого акумулювання, при цьому зростуть також втрати енергіi,, i без буферного джерела у вигляді електромережі економічні показники суто автономної енергосистеми будуть значно гіршими. Так, для прикладу (9) заміна частини генерації на ВEC та СEC номінальною потужністю $P_{0}$ кожна потреба у акумулюванні зросте приблизно утричі; точніші розрахунки мають враховувати конкретні погодні умови, тип обладнання, тощо.

Висновки. Невизначеність стосовно режимів споживання електроенергії в обмежених енергосистемах гібридного типу спричиняє завищену потребу в резервних або акумулюючи потужностях. Натомість врахування можливостей щоденного прогнозування значно зменшує потребу в потужності та ємності акумуляторів при збереженні тої ж надійності енергопостачання. Застосування ВДЕ вимагатиме значно більшого акумулювання, при цьому зростуть також втрати енергії, і без буферного джерела у вигляді електромережі показники суто автономної енергосистеми будуть значно гіршими. Точні показники мають враховувати конкретні метео- та географічні умови, тип обладнання, характер споживання. Додатково треба враховувати швидкодію акумуляторів, що потребуватиме більшої часової дискретності, хоча б хвилинних градацій по часу. Ці питання $є$ темою наступних досліджень.

Стаття підготовлена в рамках виконання проектів науково-технічних робіт Національної академії наук України: «Комплекс-С», «Комплекс-3» (КПКВК 6541030).

1. Дерев'янко Д.Г. Оцінювання ефективності регулювання енергетичних процесів в локальних електротехнічних системах 3 джерелами розосередженої генерації. Автореферат дисертації канд. техн. наук: 05.09.03. Київ. НТУУ «КПІ». 2016. 20 с.

2. Swati Negi, Lini Mathew. Hybrid Renewable Energy System: A Review. International Journal of Electronic and Electrical Engineering. 2014, Vol. 7. No. 5. Pp. 535-542.

3. Shivarama K.K., Sathish K.K. A review on hybrid renewable energy systems. Renewable and Sustainable Energy Reviews. 2015. Vol. 52. Pp. 907-916. doi org/10.1016/j.rser.2015.07.187

4. Bhandari B., Lee K.-T., Lee G.-Y., Cho Y.-M., Ahn S.$H$. Optimization of Hybrid Renewable Energy Power Systems: A Review. International journal of precision engineering and manufacturing-green technology. 2015. Vol. 2. No. 1. Pp. 99-112.

5. Wu Y.-K., Chang Sh.-M.. Review of the Optimal Design on a Hybrid Renewable Energy System. MATEC Web of Conferences 55. 06001.2016. doi: 10.1051/matecconf/ 20165506001

6. Sawle Y., Gupta S.C., Kumar Bohre A.. Review of hybrid renewable energy systems with comparative analysis of 
off-grid hybrid system. Renewable and Sustainable Energy Reviews. 2018. Vol. 81. Part 2. Pp. 2217-2235.

doi: $\operatorname{org} / 10.1016 /$ j.rser.2017.06.033.

7. Kyari I.B., Ya'u M.J. Hybrid Renewable Energy Systems for Electrification. A Review. Science Journal of Circuits. Systems and Signal Processing. 2019. No. 8(2). Pp. 3239. doi:10.11648/j.cssp.20190802.11.

8. Lawan S.M., Zainal W.A. A Review of Hybrid Renewable Energy Systems Based on Wind and Solar Energy. Modeling, Design and Optimization. In book: Wind Solar Hybrid Renewable Energy System, 2020. 23 p. doi: 10.5772/intechopen.85838.

9. Dawood F., Shafiullah G.M., Anda M. Stand-Alone Microgrid with $100 \%$ Renewable Energy. A Case Study with Hybrid Solar PV-Battery-Hydrogen. Sustainability. 2020. No. 12. doi: 10.3390/su12052047.

10. Єдиний державний веб-портал відкритих даних. [Електронний ресурc]. URL: https://data.gov.ua/dataset.

11. Національний класифікатор України: класифікація видів економічної діяльності ДК 009:2010.

12. Альбом типових графіків електричних навантажень. Міненерговугілля України. 2017 p [Електронний pecypc]. URL: http://mpe.kmu.gov.ua/minugol/c ontrol/publish/article?art_id=245201705.

13. Лисенко O.B. Оцінка випадкових властивостей рівнів споживання електроенергії. Відновлювана енергетика. 2018. № 1. С. 26-35.

14. Кузнєцов М.П. Побудова математичної моделі режиму споживання електроенергії. Відновлювана енергетика. 2017. № 4. С. 33-42.

15. Olsson M., Perninge M., Soder L. Modeling real-time balancing power demands in wind power systems using stochastic differential equations. Electric Power Systems Research. 2010. No. 80. Pp. 966-974.

16. Кузнсцов М.П., Лисенко О.В. Характер балансування потужності в локальній енергосистемі 3 відновлюваними джерелами енергії. Науковий вісник Таврійського державного агротехнологічного університету. 2019. Вип. 9. Т.1. С. 1-11. doi: 10.31388/2220-8674-2019-1-17.

17. Kuznietsov M., Vyshnevska Yu., Brazhnyk I., Melnyk $O$. Modeling of the Generation-Consumption Imbalance in the Heterogeneous Energy Systems with Renewable Energy Sources. 2019 IEEE 6th International Conference on Energy Smart Systems (ESS) conference-paper. Pp. 196-200. DOI: 10.1109/ess.2019.8764189.

\section{REFERENCES}

1. Derevianko D. Otsinyuvannya efektyvnosti rehulyuvannya enerhetychnykh protsesiv $\mathrm{v}$ lokalnykh elektrotekhnichnykh systemakh z dzherelamy rozoseredzhenoyi heneratsiyi. [Evaluation of the effectiveness of regulation of energy processes in the local electrical systems with DG sources]. Thesis on the competition of graduate degree on the specialty 05.09.03. NTUU «Kyiv Polytechnic Institute». 2016. 20 p. [in Ukrainian].

2. Swati Negi, Lini Mathew. Hybrid Renewable Energy System: A Review. International Journal of Electronic and Electrical Engineering. 2014, Vol. 7. No. 5. Pp. 535-542. [in English].

3. Shivarama K.K., Sathish K.K. A review on hybrid renewable energy systems. Renewable and Sustainable Energy Reviews. 2015. Vol. 52. Pp. 907-916. DOI: org/10.1016/j.rser.2015.07.187. [in English].

4. Bhandari B., Lee K.-T., Lee G.-Y., Cho Y.-M., Ahn S.-H. Optimization of Hybrid Renewable Energy Power Systems: A Review. International journal of precision engineering and manufacturing-green technology. 2015. Vol. 2. No. 1. Pp. 99112. [in English].

5. Wu Y.-K., Chang Sh.-M. Review of the Optimal Design on a Hybrid Renewable Energy System. MATEC Web of Conferences 55. 06001.2016. doi: 10.1051/matecconf/ 20165506001. [in English].

6. Sawle Y., Gupta S.C., Kumar Bohre A.. Review of hybrid renewable energy systems with comparative analysis of off-grid hybrid system. Renewable and Sustainable Energy Reviews. 2018. Vol. 81. Part 2. Pp. 2217-2235. doi: org/10.1016/j.rser.2017.06.033. [in English].

7. Kyari I.B., Ya'u M.J. Hybrid Renewable Energy Systems for Electrification. A Review. Science Journal of Circuits. Systems and Signal Processing. 2019. No. 8(2). Pp. 3239. doi:10.11648/j.cssp.20190802.11. [in English].

8. Lawan S.M., Zainal W.A. A Review of Hybrid Renewable Energy Systems Based on Wind and Solar Energy. Modeling, Design and Optimization. In book: Wind Solar Hybrid Renewable Energy System, 2020. 23 p. doi: 10.5772/intechopen.85838. [in English].

9. Dawood F., Shafiullah G.M., Anda M. Stand-Alone Microgrid with $100 \%$ Renewable Energy. A Case Study with Hybrid Solar PV-Battery-Hydrogen. Sustainability. 2020. No. 12. doi: 10.3390/su12052047. [in English].

10. Yedynyy derzhavnyy veb-portal vidkrytykh danykh. [Web portal of open data]. [Electronic resource]. URL: https://data.gov.ua/dataset. [in Ukrainian].

11. Natsionalnyy klasyfikator Ukrayiny: klasyfikatsiya vydiv ekonomichnoyi diyalnosti. [National Classifier of Ukraine: Classification of Economic Activities]. DK 009:2010. [in Ukrainian].

12. Albom typovykh hrafikiv elektrychnykh navantazhen. [Album of typical charts of electrical loads]. Minenerhovuhillya Ukrayiny. [Electronic resource]. URL: http://mpe.kmu.gov.ua/minugol/control/publish/article?art_id=2 45201705. [in Ukrainian].

13. Lysenko $O$. Otsinka vypadkovykh vlastyvostei rivniv spozhyvannia elektroenerhii. [Estimation of random properties of electricity consumption levels]. Vidnovluvana energetika. 2018. No. 1(52). Pp. 26-35. [Electronic resource]. URL: http://ve.org.ua/index.php/journal/article/view/8. [in Ukrainian]

14. Kuznietsov $M$. Pobudova matematychnoi modeli rezhymu spozhyvannia elektroenerhii. [Construction of a mathematical model of electricity consumption mode]. Vidnovluvana energetika. 2017. No. 4(51). Pp. 33-42. [Electronic resource]. URL: http://ve.org.ua/index.php/journal/ar ticle/view/19. [in Ukrainian].

15. Olsson M., Perninge M., Soder L. Modeling real-time balancing power demands in wind power systems using stochastic differential equations. Electric Power Systems Research. 2010. No. 80. Pp. 966-974. [in English].

16. Kuznietsov M., Lysenko $O$. Kharakter balansuvannya potuzhnosti $\mathrm{v}$ lokal'niy enerhosystemi $\mathrm{z}$ vidnovlyuvanymy dzherelamy enerhiyi. [The nature of power balancing in the local energy system with renewable energy sources]. Naukovyy visnyk Tavriyskoho derzhavnoho ahrotekhnolohichnoho universytetu. [Scientific Bulletin of the Tavrida State Agrotechnological University]. 2019. No. 9. Pp. 1-11. doi: 10.31388/2220-8674-2019-1-17. [in Ukrainian].

17. Kuznietsov M., Vyshnevska Yu., Brazhnyk I., Melnyk $O$. Modeling of the Generation-Consumption Imbalance in the Heterogeneous Energy Systems with Renewable Energy Sources. 2019 IEEE 6th International Conference on Energy Smart Systems (ESS) conference-paper. Pp. 196-200. doi: 10.1109/ess.2019.8764189. [in English]. 


\section{ВЛИЯНИЕ НЕСТАБИЛЬНОСТИ ПОТРЕБЛЕНИЯ НА ЭНЕРГЕТИЧЕСКИЙ БАЛАНС ГИБРИДНОЙ ЭНЕРГОСИСТЕМЫ}

М.П. Кузнецов ${ }^{1}$, докт. техн. наук, А.А. Мельник ${ }^{2}$, аспирант

${ }^{1}$ Институт возобновляемой энергетики НАН Украины, 02094, ул. Г.Хоткевича, 20А, г. Киев, Украина.

${ }^{2}$ Национальный технический университет Украины «Киевский политехнический институт им.И.Сикорского», 03056, пр-т. Победы, 37, г. Киев, Украина.

Цель данной работь - разработка модели балансирования процессов генерации и потребления электроэнергии для случаев ограниченной или недостаточной информачии о нагрузке на энергетическую систему. При отсутствии достаточных исторических данных об этих прочессах для моделирования используются обобщенные статистические показатели. Этим обусловлены завышенные требования к потребностям в резервных мощностях и системах аккумулирования энергии. Предметом исследования являются гибридные электроэнергетические системы, используюшие традиционые и возобновляемые источники энергии и обладающие свойствами локальной сети. Такие системы чувствительны $\kappa$ переменным режсимам потребления энергии, которые усложняют оценку текущей нагрузки. Наличие ветровых и солнечных электростанций затрудняет обеспечение баланса мощности, увеличивает потребность в промежуточном аккумулировании энергии. Методом исследования локальной системь является математическое моделирование случайных прочессов потребления и генерации энергии. Источником информации о потреблении являются статистические данные о работе отдельных потребителей, которые имеют ограниченную потребность в электрической энергии и заинтересованы в автономных источниках. Для таких потребителей перспективным является применение рассредоточенной генерации, в том числе с использованием местных источников солнечной и ветровой энергии. Данные о различных потребителях объединены в группы 6 соответствии с государственной классификацией видов экономической деятельности. Тогда прочесс балансирования мощности можно рассматривать как суперпозицию случайных процессов генерации $u$ потребления. Предложенная модель представления нагрузки позволяет имитировать реальные процессы таким образом, чтобы результаты совпадали с имеющимися статистическими данными. Результаты исследования позволяют сравнивать различные варианты энергосистемы по сбалансированию и потребностями в аккумулировании энергии. Библ.17, табл.1, рис.4.

Ключевые слова: гибридная энергосистема, возобновляемые источники энергии, энергобаланс, случайный прочесс, аккумулирование электроэнергии. 